\title{
Деминерализация растворов гетероциклической аминокислоты электромембранным методом
}

\author{
(c) 2021 Елисеева Т.В., Харина А.Ю., Черникова Е.Н., Чарушина О.Е. \\ Воронежский государственный университет, Воронеж
}

Поступила в редакцию 16.07.2021 г.

DOI: $10.17308 /$ sorpchrom.2021.21/3633

Перспективным методом деминерализации растворов аминокислот является электродиализ с ионообменными мембранами. Цель данной работы - установление влияния природы минеральных примесей на эффективность их извлечения из растворов гетероциклической аминокислоты - пролина (Pro), а также на потери продукта в процессе электромембранного обессоливания. В задачи работы входит изучение массопереноса пролина через гетерогенные ионообменные мембраны при электродиализе его индивидуального водного раствора. Показано, что поток гетероциклической аминокислоты из индивидуального раствора больше через катионообменную мембрану МК-40, чем через анионообменную МА-41. Величина предельного диффузионного тока также выше для мембраны МК-40, а форма зависимости потока пролина от плотности тока является традиционной для амфолитов при электродиализе. В исследовании смешанных растворов аминокислоты и минеральной соли выявлен конкурентный транспорт минеральных ионов через ионообменные мембраны, приводящий к снижению массопереноса Рro по сравнению с индивидуальным раствором. Отмечено, что значения потоков данной гетероциклической аминокислоты через мембрану МА-41 в присутствии различных минеральных ионов в интенсивном токовом режиме увеличиваются в последовательности: $\mathrm{Cl}^{-}<\mathrm{NO}_{3}{ }^{-}<\mathrm{SO}_{4}{ }^{2-}$. Выявлена следующая корреляция для исследуемых систем: большей подвижности иона в фазе мембраны соответствуют большие значения его потоков. Кроме того, потоки гетероциклической аминокислоты через мембрану МК-40 возрастают в корреляции с увеличением энергии гидратации положительно гидратированного катиона неорганического электролита. Оценка параметров деминерализации - степени обессоливания и потерь аминокислоты показала, что среди исследованных растворов в одинаковых экспериментальных условиях наиболее полно процесс деминерализации проходит в системе пролин + нитрат натрия, а наименьшие потери целевого продукта зафиксированы при электродиализе в системе пролин + хлорид аммония. Для эффективного разделения гетероциклической аминокислоты и минеральной соли методом электродиализа необходим учет влияния природы ионов минеральной соли, их гидратации, подвижности в фазе ионообменной мембраны и в растворе.

Ключевые слова: электродиализ, гетероциклическая аминокислота, ионообменные мембраны, массоперенос.

\section{Введение}

Аминокислоты широко используются в сельском хозяйстве и пищевой промышленности, а также являются важными составляющими при производстве лекарственных средств. В биотехнологии аминокислоты необходимо отделять от остатков питательной среды после микробиологического синтеза, проводить их деминерализацию, а также концентрирование. Особый интерес пред- ставляет исследование процесса деминерализации растворов гетероциклических аминокислот, содержащих различные неорганические примеси, ввиду ограниченности сведений в литературе в данной области. Одним из перспективных методов деминерализации растворов аминокислот является электродиализ с ионообменными мембранами [1, 2]. Цель данной работы - установление влияния природы минеральных примесей на эффективность их извлечения из растворов 
гетероциклической аминокислоты пролина, а также на потери продукта при электродиализе.

\section{Экспериментальная часть}

Разделение аминокислоты и минеральной соли в настоящей работе проводили методом электродиализа в семисекционном аппарате с использованием чередующихся гетерогенных катионообменных и анионообменных мембран марок МК-40 и МА-41 соответственно (производство ООО ОХК «Щекиноазот», Россия) (рис. 1). Использованы модельные растворы гетероциклической аминокислоты пролина (Pro), а также смешанные растворы данного амфолита с различными минеральными солями: $\mathrm{NaCl}, \mathrm{NH}_{4} \mathrm{Cl}, \mathrm{NaNO}_{3}, \mathrm{Na}_{2} \mathrm{SO}_{4}$. Концентрация Pro в растворах, моделирующих обессоливаемый раствор после микробиологического синтеза и предочистки, была равна $0.02 \mathrm{M}$, минеральной соли $0.01 \mathrm{M}$. Значения $\mathrm{pH}$ всех подаваемых смесей были близки к изоэлектрической точке пролина $(\mathrm{pI}=6.30)$ и составляли от 5.0 до 5.9.

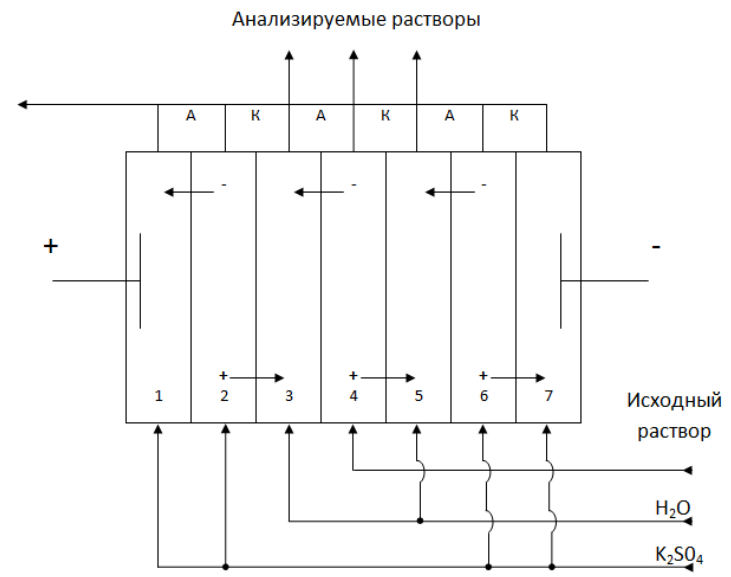

Рис. 1 Схема электродиализного аппарата с чередующимися катионо- (К) и анионообменными (А) мембранами, 1-7 - номера секций

Fig. 1 A diagram of an electrodialysis cell with alternating cation- $(\mathrm{K})$ and anion-exchange

(A) membranes, (1-7) section numbers

\section{Обсуждение результатов}

В ходе данной работы проведен сравнительный анализ потоков гетероциклической аминокислоты через катионообменную мембрану МК-40 и анионообменную мембрану МА-41 при электродиализе индивидуального раствора пролина (Pro) в зависимости от плотности тока (рис. 2).

Выявлен нелинейный характер полученных зависимостей, обусловленный действием барьерного эффекта [3] и эффекта облегчённой электромиграции [4].

Установлено, что величина предельной плотности тока, определяемая по максимуму, наблюдаемому на зависимостях потоков аминокислоты от плотности тока, больше для мембраны МК-40, чем для МА-41. Значение величины предельной плотности тока для МК-40 составило $0.32 \mathrm{MA} \cdot \mathrm{cm}^{-2}$, для МА-41 $0.26 \mathrm{MA} \cdot \mathrm{cm}^{-2}$.

Обнаружено, что значения потоков Pro через катионообменную мембрану больше, чем через анионообменную. Это может быть обусловлено тем, что в растворе камеры деионизации электродиализного аппарата значение $\mathrm{pH}$ составляет 5.5, и доля аминокислоты в форме

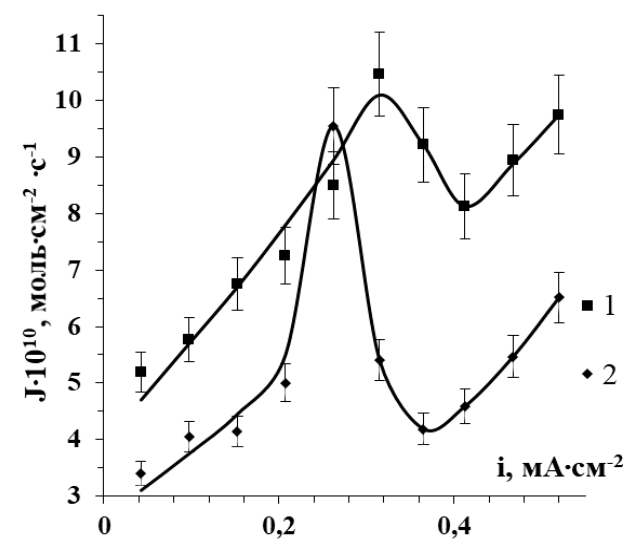

Рис.2 Зависимость потоков аминокислоты через мембрану: 1 - МК-40, 2 - МА-41 от плотности тока при электродиализе раствора Pro $(0.02 \mathrm{M})$

Fig. 2 Dependence of amino acid fluxes passing through the membrane: (1) MK-40,

(2) MA-41 on the current density in the electrodialysis of a Pro solution (0.02M) 


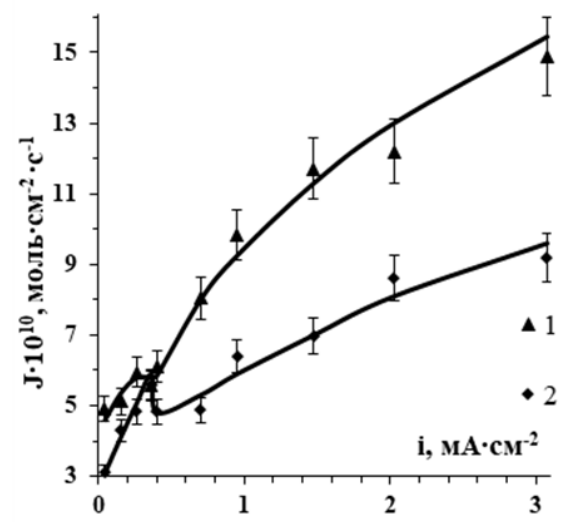

Рис. 3. Зависимость потоков аминокислоты через мембрану: 1 - МК-40,

2 - МА-41 от плотности тока при электродиализе раствора Pro $(0.02 \mathrm{M})+\mathrm{NaCl}$ $(0.01 \mathrm{M})$

Fig. 3 Dependence of amino acid fluxes passing through the membrane:

1 - MK-40, 2-MA-41 on the current density in the electrodialysis of a solution of Pro $(0.02 \mathrm{M})+\mathrm{NaCl}(0.01 \mathrm{M})$

катиона в исследуемом диапазоне значений плотности тока больше доли Pro в форме аниона $\left(3.1 \cdot 10^{-4}\right.$ и $7.9 \cdot 10^{-6}$ соответственно).

Расчет доли ионных форм аминокислоты проводился с учётом $\mathrm{pH}$ раствора, а также значений $\mathrm{pK}$ аминокислоты. В растворе камеры деионизации электродиализного аппарата значение $\mathrm{pH}$ варьировалось от 5.5 до 5.9. В исследуемом диапазоне значений плотности тока доля аминокислоты в форме катиона изменялась в диапазоне $3.1 \cdot 10^{-4}-1.2 \cdot 10^{-4}$, а доля анионов пролина - от $7.9 \cdot 10^{-6}$ до $2.0 \cdot 10^{-5}$ соответственно.

Кроме того, одной из причин выявленной особенности массопереноса аминокислоты может быть большая диффузионная проницаемость мембраны МК-40 в сравнении с МА-41.

Сравнение транспорта Рro через мембраны МК-40 и МА-41 в зависимости от плотности тока проведено также при электродиализе раствора аминокислоты в смеси с хлоридом натрия (рис. 3).

Отмечается менее ярко выраженный, чем в случае с индивидуальным раствором, нелинейный характер зависимости потока Pro от плотности тока. В интен-

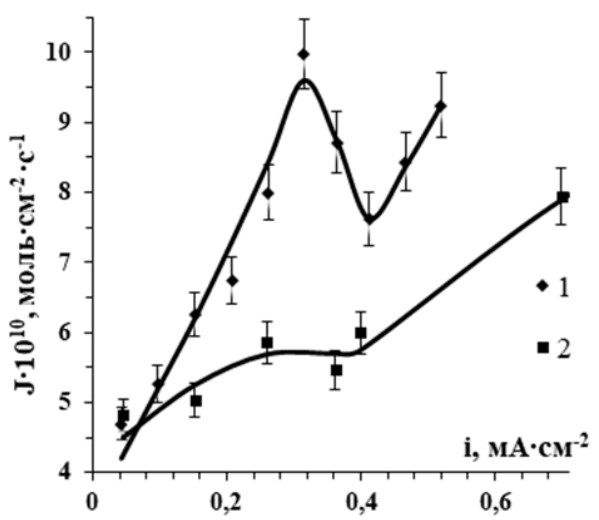

Рис. 4. Зависимость потоков аминокислоты через мембрану МК-40 от плотности тока при электродиализе:

1 - раствора Pro $(0.02 \mathrm{M}), 2$ - раствора Pro $(0.02 \mathrm{M})+\mathrm{NaCl}(0.01 \mathrm{M})$

Fig. 4 Dependence of amino acid fluxespassing through the MK-40 membrane on the current density in the electrodialysis of: 1 - Pro solution $(0.02 \mathrm{M}), 2$ - Pro solution $(0.02 \mathrm{M})+\mathrm{NaCl}(0.01 \mathrm{M})$

сивном токовом режиме наблюдается больший массоперенос Pro через мембрану МК-40, чем через МА-41. Сравнительный анализ потоков Pro из индивидуального и смешанного растворов через ионообменные мембраны показал наличие конкурентного транспорта ионов минеральной соли, сопровождающегося снижением потоков Pro в присутствии ионов неорганического электролита. На рис. 4 показаны полученные зависимости потоков Pro через мембрану МК-40 из индивидуального и смешанного растворов от плотности тока.

Одной из задач работы стало исследование процесса деминерализации раствора Pro, содержащего различные минеральные соли, методом электродиализа. На зависимостях потоков аминокислоты через ионообменные мембраны от плотности тока при электродиализе смешанных растворов Pro с неорганическими солями наблюдается максимум, который соответствует предельному диффузионному току. Затем потоки снижаются вследствие действия барьерного эффекта. При дальнейшем увеличении плотности тока действие барьерного эффекта сменяется действием эффекта 


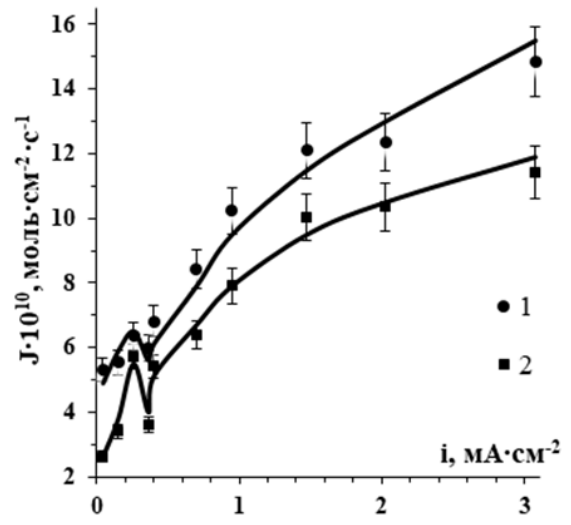

Рис. 5. Зависимость потоков Pro через мембрану МК-40 от плотности тока в присутствии ионов: $1-\mathrm{Na}^{+}, 2-\mathrm{NH}_{4}{ }^{+}$ при электродиализе раствора аминокислота - минеральная соль

Fig. 5 Dependence of Pro fluxes passing through the MK-40 membrane on the current density in the presence of ions: $1-\mathrm{Na}^{+}, 2-$ $\mathrm{NH}_{4}{ }^{+}$in the electrodialysis of an amino acid - mineral salt solution

облегченной электромиграции - явления увеличения потоков амфолита из-за его сопряженного транспорта с продуктами диссоциации растворителя - воды.

Необходимо отметить, что больших значений достигают потоки Pro через MК-40 в присутствии катионов $\mathrm{Na}^{+}$, чем в присутствии катионов $\mathrm{NH}_{4}{ }^{+}$во всем диапазоне исследуемых значений плотности тока (рис. 5). С увеличением энергии гидратации катионов [5] отмечаются большие потоки аминокислоты. Это связано с увеличением количества Pro, входящего в гидратную оболочку катионов минеральной соли и переносимого с ними через катионообменную мембрану.

При исследовании зависимости массопереноса катионов минеральных солей от плотности тока можно отметить, что потоки ионов $\mathrm{NH}_{4}{ }^{+}$достигают больших значений, чем для ионов $\mathrm{Na}^{+}$. Отмечено, что полученные значения потоков коррелируют как с подвижностью ионов в растворе, так и подвижностью ионов в мембране МК-40. Как известно, подвижность катионов $\mathrm{Na}^{+}$меньше, чем катионов $\mathrm{NH}_{4}^{+}$[6]. Следует также отметить небольшое различие в зависимостях $\mathrm{pH}$ секции обессоливания от плотности тока

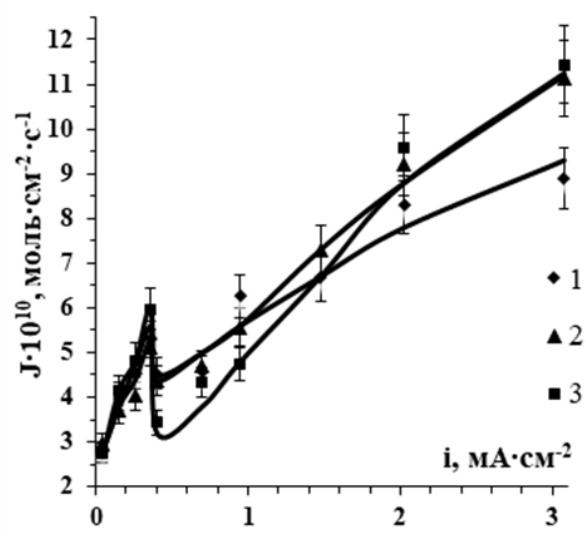

Рис. 6. Зависимость потоков Pro через мембрану MA-41 от плотности тока в присутствии минеральных ионов: $1-\mathrm{Cl}^{-}, 2-\mathrm{NO}_{3}^{-}, 3-\mathrm{SO}_{4}^{2-}$ при электродиализе раствора аминокислота - минеральная соль

Fig. 6. Dependence of Pro fluxes passing through the MA-41 membrane on the current density in the presence of mineral ions: $1-\mathrm{Cl}^{-}, 2-\mathrm{NO}_{3}^{-}, 3-\mathrm{SO}_{4}^{2-}$ in the electrodialysis of an amino acid - mineral salt solution

при электродиализе растворов, содержащих хлорид натрия и хлорид аммония. Так как хлорид аммония является солью, подвергающейся гидролизу, значение $\mathrm{pH}$ исходного смешанного раствора несколько ниже, однако из-за буферного действия аминокислоты и снижения содержания ионов аммония в секции обессоливания с ростом плотности тока значительных различий зависимостей $\mathrm{pH}-\mathrm{i}$ для двух солей не наблюдается.

Для изучения особенностей процесса обессоливания гетероциклической аминокислоты были рассмотрены также зависимости потоков Pro через анионообменную мембрану МА-41 от плотности тока в присутствии исследуемых анионов минеральных солей (рис. 6).

Значимое различие в массопереносе аминокислоты в присутствии различных анионов минеральной соли выявляется в интенсивном токовом режиме. При этом потоки Pro увеличиваются в ряду: $\mathrm{Cl}^{-}<\mathrm{NO}_{3}{ }^{-}<\mathrm{SO}_{4}{ }^{2-}$. Потоки аминокислоты в присутствии анионов $\mathrm{Cl}^{-}$достигают наименьших значений, что можно объяснить наиболее ярко выраженным конкурентным транспортом Pro и анионов $\mathrm{Cl}^{-}$. Наличие в системе двухзарядных 
Таблица 1. Значения количественных характеристик процесса деминерализации растворов аминокислота - минеральная соль методом электродиализа при $\mathrm{i}=3 \mathrm{MA} \cdot \mathrm{cm}^{-2}$

Table 1. Values of quantitative characteristics of the demineralisation process of an amino acid - mineral salt solutions by electrodialysis at $\mathrm{i}=3 \mathrm{~mA} \mathrm{~cm}^{-2}$

\begin{tabular}{|c|r|c|c|c|}
\hline Характеристика & Pro $+\mathrm{NaCl}$ & Pro $+\mathrm{NaNO}_{3}$ & Pro $+\mathrm{Na}_{2} \mathrm{SO}_{4}$ & Pro $+\mathrm{NH}_{4} \mathrm{Cl}$ \\
\hline$\alpha_{\max }$ & 92.5 & 93.4 & 78.3 & 92.9 \\
\hline $\mathrm{L}_{\max }$ & 10.3 & 10.7 & 11.7 & 9.60 \\
\hline
\end{tabular}

анионов $\mathrm{SO}_{4}{ }^{2-}$ в наименьшей степени ограничивает транспорт аминокислоты.

В работе проведено сравнение потоков анионов различных минеральных солей через анионообменную мембрану в присутствии Pro. Исследование массопереноса анионов минеральных солей в запредельных условиях электродиализа показало, что потоки исследуемых анионов через мембрану МА-41 увеличиваются в ряду: $\mathrm{SO}_{4}{ }^{2-}<\mathrm{Cl}^{-}<\mathrm{NO}_{3}{ }^{-}$и коррелируют с величинами подвижности данных ионов в фазе исследуемой анионообменной мембраны, однако не соответствуют ряду подвижности в растворе, которая изменяется следующим образом: $\mathrm{NO}_{3}{ }^{-}<\mathrm{Cl}^{-}<\mathrm{SO}_{4}{ }^{2-}[6]$.

При малых токах наблюдается линейная зависимость потоков анионов минеральной соли от плотности тока. В интенсивном токовом режиме фиксируется уменьшение угла наклона кривых, что связано с уменьшением концентрации ионов минеральной соли у поверхности мембран в камере обессоливания и участием в массопереносе образующихся продуктов диссоциации воды.

С целью выявления наиболее оптимальных условий проведения разделения Pro и минеральной соли были рассчитаны основные параметры процесса электродиализной деминерализации раствора аминокислоты: потери аминокислоты

\section{Список литературы}

1. Aghajanyan A., Saribekyan Z., Saghyan A. // Separation and Purification Technology. 2019. Vol. 55. pp 771-778.

2. Yuan F., Wang Q., Yang P., Cong W. // Separation and Purification Technology. 2016. Vol. 168. pp 257-264.
$(\mathrm{L}, \%)$ и степень обессоливания $(\alpha, \%)$ (табл.1).

Наибольшее значение степени обессоливания зафиксировано при электродиализе раствора Pro в смеси с $\mathrm{NaNO}_{3}$. При этом, отмечено, что наименьшие потери аминокислоты соответствуют процессу деминерализации раствора Pro c $\mathrm{NH}_{4} \mathrm{Cl}$.

\section{Заключение}

Установлено, что для эффективного разделения гетероциклической аминокислоты и минеральной соли методом электродиализа учет влияния природы ионов минеральной соли, их гидратации, подвижности в фазе ионообменной мембраны и в растворе может быть использован с целью управления процессом. Это позволяет отнести электродиализ к эффективным методам деминерализации растворов гетероциклической аминокислоты, применение которого в области действия барьерного эффекта является наиболее рациональным для деминерализации раствора Pro с малыми потерями целевого продукта. Извлечение аминокислоты с максимально высокими значениями степени обессоливания целесообразно проводить в интенсивном токовом режиме, однако, потери продукта при этом увеличиваются.

3. Shaposhnik V.A., Eliseeva T.V. // Journal of Membrane Science. 1999. Vol. 161. pp 223228.

4. Елисеева Т.В., Шапошник В.А. // Электрохимия. 2000. Т. 36. № 1. С. 73-76.

5. Самойлов О.Я. Структура водных растворов электролитов и гидратация ионов. М. Изд-во АН СССР. 1957. 173 с.

6. Шапошник В.А. Кинетика электродиализа. Воронеж. ВГУ. 1989. 176 с. 


\title{
Demineralization of heterocyclic amino acid solutions by an electromembrane method
}

\author{
(C) 2021 Eliseeva T.V., Kharina A.Yu., Chernikova E.N., Charushina O.E.
}

\author{
Voronezh State University, Voronezh
}

\begin{abstract}
Electrodialysis with ion-exchange membranes is a promising method for the demineralization of amino acid solutions. The aim of this work is to establish the effect of the nature of mineral impurities on the efficiency of their extraction from solutions of a heterocyclic amino acid, proline (Pro), as well as on the losses of the product in the process of electromembrane desalination. Among the objectives of the research was to study proline mass transfer through heterogeneous ion-exchange membranes in the electrodialysis of its individual aqueous solution. It was shown that the flux of the heterocyclic amino acid from the individual solution through the MK-40 cation-exchange membrane was heavier than through the MA-41 anionexchange membrane. The value of the diffusion-limited current was also higher for the MK-40 membrane, and the form of the dependence of the proline flux on the current density was conventional for the electrodialysis of ampholytes. The study of mixed solutions of an amino acid and a mineral salt revealed a competitive transport of mineral ions through ion-exchange membranes leading to a decrease in the mass transfer of Pro as compared with the individual solution. It was noted that the values of the fluxes of the given heterocyclic amino acid passing through the MA-41 membrane in the presence of various mineral ions at high current density increased in the sequence: $\mathrm{Cl}^{-}<\mathrm{NO}_{3}{ }^{-}<\mathrm{SO}_{4}{ }^{2-}$. The following correlation was revealed for the studied systems: the higher ion mobility in the membrane phase corresponds to higher values of its fluxes. In addition, the fluxes of a heterocyclic amino acid through the MK-40 membrane increase in correlation with an increase in the hydration energy of the positively hydrated cation of an inorganic electrolyte. The estimeted demineralization parameters (the degree of desalination and amino acid losses) showed that among the studied solutions the process of demineralization conducted under the same experimental conditions was most evident in the proline + sodium nitrate system, and the smallest losses of the target product were recorded in the electrodialysis in the proline + ammonium chloride system. The effective separation of a heterocyclic amino acid and a mineral salt by the method of electrodialysis requires taking into account the influence of the nature of mineral salt ions, their hydration, and mobility in the phase of the ion-exchange membrane and in the solution.
\end{abstract}

Keywords: electrodialysis, heterocyclic amino acid, ion-exchange membranes, mass transfer.

\section{References}

1. Aghajanyan A., Saribekyan Z., Saghyan A., Separation and Purification Technology, 2019, Vol. 55, pp. 771-778. DOI: 10.1080/01496395.2019.1574820

2. Yuan F., Wang Q., Yang P., Cong W., Separation and Purification Technology, 2016, Vol. 168, pp. 257-264.

3. Shaposhnik V.A., Eliseeva T.V., Journal of Membrane Science, 1999, Vol. 161, pp. 223228.

Елисеева Татьяна Викторовна - зав. кафедрой аналитической химии, к.Х.н., Воронежский государственный университет, Воронеж

Харина Анастасия Юрьевна - к.Х.н., ведущий инженер кафедры аналитической химии, Воронежский государственный университет, Воронеж

Черникова Екатерина Николаевна - студент, Воронежский государственный университет, Воронеж

Чарушина Ольга Евгеньевна - студент, Воронежский государственный университет, Воронеж
4. Eliseeva T.V., Shaposhnik V.A., Russian Journal of Electrochemistry, 2000, Vol. 36, No 1, pp. 64-67.

5. Samoilov O.Y. Struktura vodnyh rastvorov elektrolitov i gidrataciya ionov, M., Publishing House of the Academy of Sciences of the USSR, 1957, $173 \mathrm{p}$.

6. Shaposhnik V.A., Kinetika elektrodializa, Voronezh, VSU, 1989, 176 p.

Eliseeva Tatiana V. - Head of the Department of Analytical Chemistry, PhD in Chemistry, Voronezh State University, Voronezh, e-mail: tatyanaeliseeva@yandex.ru

Kharina Anastasia Yu. - PhD in Chemistry, Senior Engineer of the Department of Analytical Chemistry, Voronezh State University, Voronezh, e-mail: aukharina@gmail.com

Chernikova Ekaterina N. - student, Voronezh State University, Voronezh

Charushina Olga E. - student, Voronezh State University, Voronezh 
